\title{
Anti-fibrotic effects of tannic acid through regulation of a sustained TGF-beta receptor signaling
}

Eleanor B. Reed', Shawn Ard', Jennifer La', Chan Young Park², Laura Culligan², Jeffrey J. Fredberg², Larisa V. Smolyaninova ${ }^{3}$, Sergei N. Orlov ${ }^{3,4}$, Bohao Chen ${ }^{1}$, Robert Guzy ${ }^{1}$, Gökhan M. Mutlu and Nickolai O. Dulin ${ }^{1 *}$ (D)

\begin{abstract}
Background: Pulmonary fibrosis is a progressive disease characterized by structural distortion of the lungs. Transforming growth factor-beta (TGF-beta) is a key cytokine implicated in the pathogenesis of pulmonary fibrosis. TGF-beta-induced myofibroblast differentiation characterized by expression of smooth muscle alpha-actin and extracellular matrix proteins is a key process in pathogenesis of fibrotic disease. Tannic acid is a natural polyphenol with diverse applications. In this study, we investigated the effect of tannic acid on myofibroblast differentiation and pulmonary fibrosis in cultured cells and in bleomycin model of the disease.
\end{abstract}

Methods: Primary cultured human lung fibroblasts (HLF) were used. The relative levels of proteins were determined by Western blotting. HLF contraction was measured by traction microscopy. Bleomycin-induced pulmonary fibrosis in mice was used as the disease model.

Results: Tannic acid inhibited TGF-beta-induced expression of collagen-1 and smooth muscle alpha-actin (SMA) as well as force generation by HLF. Tannic acid did not affect initial phosphorylation of Smad2 in response to TGF-beta, but significantly inhibited sustained Smad2 phosphorylation, which we recently described to be critical for TGF-beta-induced myofibroblast differentiation. Accordingly, tannic acid inhibited Smad-dependent gene transcription in response to TGF-beta, as assessed using luciferase reporter for the activity of Smad-binding elements. Finally, in mouse model of bleomycin-induced pulmonary fibrosis, therapeutic application of tannic acid resulted in a significant reduction of lung fibrosis, decrease in collagen-1 content and of Smad2 phosphorylation in the lungs.

Conclusions: This study demonstrates the anti-fibrotic effect of tannic acid in vitro and in vivo through a regulation of sustained Smad2 phosphorylation.

Keywords: Tannic acid, Pulmonary fibrosis, TGF-beta, Smad2, Myofibroblast

\section{Background}

Idiopathic pulmonary fibrosis (IPF) is a progressive, fatal disease characterized by parenchymal fibrosis and structural distortion of the lungs. Age-adjusted mortality due to pulmonary fibrosis is increasing [1], and it poses a vexing clinical challenge given the lack of proven effective therapy. IPF is thought to be a disorder of

\footnotetext{
* Correspondence: ndulin@medicine.bsd.uchicago.edu

${ }^{1}$ Department of Medicine, Section of Pulmonary and Critical Care Medicine, the University of Chicago, 5841 S. Maryland Ave, MC6076, Chicago, IL 60637, USA

Full list of author information is available at the end of the article
}

abnormal wound healing [2, 3], wherein the initial trigger to the fibrotic response is injury to the alveolar epithelial cell, followed by an exuberant, non-resolving wound-healing response [4-6]. Injury of alveolar epithelial cells results in the elaboration of a fibrinous provisional matrix and activation of several pro-inflammatory, pro-coagulant, and pro-fibrotic mediators, of which Transforming Growth Factor- $\beta 1$ (TGF- $\beta 1$ ) is the most established [7-9]. TGF- $\beta 1$ has been localized to areas of fibrosis in both experimental and human pulmonary fibrosis $[7,10,11]$. Lung-targeted overexpression of TGF- $\beta 1$ results in the development of lung fibrosis in

(C) The Author(s). 2019 Open Access This article is distributed under the terms of the Creative Commons Attribution 4.0 International License (http://creativecommons.org/licenses/by/4.0/), which permits unrestricted use, distribution, and 
animals $[9,12]$. Conversely, inhibition of TGF- $\beta 1$ via soluble TGF- $\beta$ receptors can inhibit in vivo fibrogenesis $[13,14]$.

Fibroblasts, under stimulation by TGF- $\beta 1$, differentiate into myofibroblasts characterized by the de novo expression of cytoskeletal and contractile proteins, modified focal adhesion complexes [15], and components of the extracellular matrix [16-18]. Several cytoskeletal and smooth muscle proteins are expressed in myofibroblasts, including smooth muscle $\alpha$-actin (SMA), the most established marker for myofibroblast differentiation [18-21]. Functionally, this phenotypic switch is thought to increase the ability of the myofibroblast to attach to the remodeling matrix and ultimately facilitate wound contraction during healing process. However, induction of the myofibroblast phenotype is also associated with an increased resistance to apoptosis [22, 23] and secretion of extracellular matrix proteins (collagen isoforms, fibronectin, etc.) and pro-fibrotic factors (connective tissue growth factor (CTGF), insulin-like growth factor (IGF-1), etc. [16, 24]), thus perpetuating ongoing tissue remodeling and fibrosis. Myofibroblasts are invariably found in histologic sections of human lung specimens from patients with pulmonary fibrosis and are thought to be a critical pathogenic mechanism responsible for the progressive nature of IPF. Disrupting cellular mechanisms responsible for the acquisition of the myofibroblast phenotype may be a potential strategy to attenuate the ongoing fibrotic response in pulmonary fibrosis.

Tannic acid is a natural polyphenol found from tara pods, gallnuts and leaves of certain plants [25]. Tannic acid has been used for chemical staining of cellulose fibers (wood, textile), as a fixative-mordant in ultrastructural microscopy studies, as aroma compound in certain drinks, and for treatment of burns in humans [26]. Recent studies have demonstrated the protective effect of tannic acid in a rat model of cardiac hypertrophy and fibrosis [27], and in a mouse model of liver fibrosis [28]. We have observed that tannic acid is a potent inhibitor of myofibroblast differentiation and sought to determine its anti-fibrotic action in vitro and in mouse model of pulmonary fibrosis, and to assess the mode of its action.

\section{Materials and methods}

\section{Primary culture of human lung fibroblasts (HLF)}

Human lung fibroblasts (HLF) were isolated from human lungs rejected for transplantation through the Regional Organ Bank of Illinois (ROBI)/Gift of Hope. Human lung tissue samples were placed in DMEM with antibiotics. Lung tissue was minced to $\sim 1 \mathrm{~mm}^{3}$ pieces, washed, and plated on $10-\mathrm{cm}$ plates in growth media containing DMEM supplemented with 10\% FBS and antibiotics. The media was changed twice a week. After approximately 2 weeks, the explanted and amplified fibroblasts were cleared from the tissue pieces, trypsinized and further amplified as passage-1. For experiments, cells were grown in 12-well plates at a density of $1 \times 10^{5}$ cells per well in a growth media for $24 \mathrm{~h}$, starved in DMEM containing $0.1 \%$ bovine serum albumin (BSA) for $24 \mathrm{~h}$, and treated with desired drugs for various times as indicated in the figure legends. Primary cultures were used from passage 3 to 9 .

\section{Cell lysis and Western blotting}

Cells were lysed in urea buffer containing $8 \mathrm{M}$ deionized urea, $1 \%$ SDS, $10 \%$ glycerol, $60 \mathrm{mM}$ Tris- $\mathrm{HCl} \mathrm{pH} 6.8$, $0.02 \%$ pyronin $\mathrm{Y}$, and $5 \% \beta$-mercaptoethanol. Lysates were sonicated for $5 \mathrm{~s}$. Samples were then subjected to polyacrylamide gel electrophoresis and Western blotting with desired primary antibodies and corresponding horseradish peroxidase (HRP)-conjugated secondary antibodies, and developed by chemiluminescence reaction (Pierce). Digital chemiluminescent images below the saturation level were obtained with a LAS-4000 analyzer, and the light intensity was quantified using Multi Gauge software (Fujifilm).

\section{Traction microscopy}

To measure contractile force of human lung fibroblasts cells, we used Fourier transform traction microscopy (FTTM) $[29,30]$. The principle of this assay is to measure the deformation of a soft substrate caused by cells and to convert this measured deformation to traction (contractile force per unit area) exerted by the cells [29]. We fabricated polyacrylamide (PA) gels of which modulus is $9.6 \mathrm{kPa}$ and on which $0.2 \mu \mathrm{m}$ fluorescent beads were coated to visualize gel deformation [30]. After coating the PA gels with bovine collagen $(40 \mu \mathrm{g} / \mathrm{mL})$, cells were seeded on the PA gel in near confluency. Cells deform the gel by exerting traction and the deformation on PA gels resulted in the displacements of fluorescent beads. Bead displacements were measured by comparing the positions of beads before seeding cells and after the drug treatments. Based on the displacement fields, cellular traction was calculated using FTTM [29, 30]. Root mean square traction was used as an average contractile force magnitude of HLF cells [30].

\section{Bleomycin-induced pulmonary fibrosis}

9-10 week old C57BL/6 mice were intratracheally instilled with $1 \mathrm{U} / \mathrm{kg}$ bleomycin. Tannic acid was administered intraperitoneally daily at a dose of $10 \mathrm{mg} / \mathrm{kg}$ beginning on day-7 post-bleomycin treatment. Mice were sacrificed on day-21. Due to a patchy nature of fibrosis in this model bilateral lungs from each mouse were subjected for either histochemical, or for biochemical analysis. 


\section{Morphological analysis of pulmonary fibrosis}

Lungs were inflation fixed in $10 \%$ formalin solution in saline, all five lobes were paraffin imbedded; and lung sections were stained with haematoxylin and eosin stain (H\&E). 40X images of the H\&E-stained sections were obtained on a CRi Pannoramic whole slide scanner which creates an image without showing the slide name (unless inquired). The severity of fibrosis was first blindly assessed on scanned images by two investigators using modified Ashcroft scoring system [31]. Up to 150 fields at 10X magnification covering whole lobes were scored using Panoramic View program with "preview tracking history" function turned on, and the average score for each lung was calculated. The means \pm SD were then calculated for each experimental group. The extent of fibrosis was then assessed by measuring lung tissue surface area. Five representative $10 \mathrm{X}$ images from each lobe (devoid of airways or blood vessels) were captured, and the lung tissue surface area was measured using ImageJ program as follows. The total area was first quantified using the Analyze-Measure function. The white area (representing empty spaces) was then selected (with brightness set at 240) under the Image Adjust - Color Threshold function, and was quantified using the Analyze-Measure function. The lung tissue surface area was then calculated by subtracting the white area from the total area and expressed as a fraction of the total area. Finally the histologic score of fibrosis was calculated by multiplying the Ashcroft score by fraction of the lung tissue surface area for each lung, analogous to previously described approach $[32,33]$. The means $\pm S D$ were then calculated for each experimental group.

For biochemical analysis, isolated lungs were rapidly homogenized for $15 \mathrm{~s}$ at maximum speed in $2 \mathrm{ml}$ icecold PBS using tissue homogenizer. Homogenized samples were then mixed 1:1 (v/v) with $12 \mathrm{~N}$ hydrochloric acid for hydroxyproline assay, or mixed 3:1 with $4 \mathrm{X}$ Laemmli sample buffer, boiled for $5 \mathrm{~min}$, sonicated for 5 $\mathrm{s}$, and used for analysis by Western blotting.

\section{Hydroxyproline assay}

The hydroxyproline assay was performed as described previously [34]. Briefly, lung homogenates were mixed 1: $1(\mathrm{v} / \mathrm{v})$ in $12 \mathrm{~N}$ hydrochloric acid and hydrolyzed for 12 $\mathrm{h}$ at $110^{\circ} \mathrm{C}$. An aliquot was evaporated, resuspended in citrate-acetate buffer with chloramine $\mathrm{T}$ and left at room temperature for $20 \mathrm{~min}$. Ehrlich's solution was then added, and samples were heated at $65^{\circ} \mathrm{C}$ for $15 \mathrm{~min}$. After cooling to room temperature, absorbance was measured at $550 \mathrm{~nm}$. Hydroxyproline content was determined against a standard curve generated from pure hydroxyproline.

\section{Luciferase assay for Smad-dependent gene transcription}

Smad-dependent gene transcription was assessed using the luciferase reporter driven by four copies of Smad binding elements (SBE4-Luc) whose efficiency and selectivity for Smad activation was demonstrated previously [35]. Subconfluent cells were co-transfected with cDNA for SBE4-Luc and for a control thymidine kinase (TK) promoter-driven Renilla luciferase plasmid (pRL-TK). Cells were serum-starved, followed by stimulation with $1 \mathrm{ng} / \mathrm{ml}$ TGF- $\beta$ with or without tannic acid for $48 \mathrm{~h}$. Cells were washed and then lysed in protein extraction reagent. Lysates were assayed for firefly and Renilla luciferase activity using the dual luciferase assay kit (Promega). To account for differences in transfection efficiency, firefly luciferase activity of each sample was normalized to Renilla luciferase activity.

\section{Materials}

Tannic acid was from Sigma-Aldrich (catalog \# 403040). TGF- $\beta$ was from EMD Millipore (catalog \# GF111). Pharmaceutical grade bleomycin was from Teva Pharmaceuticals. Antibodies for Western blotting against SM $\alpha$-actin (catalog \# A5228), $\beta$-actin (catalog \# A5441), and $\alpha$-tubulin (catalog \# T6074) were from Sigma-Aldrich; against human collagen-1A1 was from Santa Cruz Biotechnology (catalog \# sc-28657); against mouse collagen 1 was from EMD Millipore (catalog \# 234167); against Smad2 (catalog \# L1603) and phospho-Smad2 (catalog \# 13804) from Cell Signaling Technology. The SBE4-Luc plasmid was kindly provided by Dr. Bert Vogelstein (The Johns Hopkins University School of Medicine, Baltimore, MD). pRL-TK plasmid was from Promega.

\section{Statistical analysis}

Quantitative data were analyzed by Student's T-test. Values of $p<0.05$ were considered statistically significant.

\section{Results}

Figure 1 shows that tannic acid potently and dose-dependently inhibits TGF- $\beta$-induced expression of collagen-1 and smooth muscle $\alpha$-actin (SMA) without affecting $\beta$-actin levels in primary cultured human lung fibroblasts (HLFs) (Fig. 1a, b). Treatment of HLF with TGF- $\beta$ resulted in a dramatic increase in cell force generation as measured by traction microscopy; and this effect was abolished by pretreatment with tannic acid (Fig. 1c). These data suggest that tannic acid is a powerful inhibitor of myofibroblast differentiation in response to TGF- $\beta$ in cultured cells.

TGF- $\beta$ signals through activation of TGF- $\beta$ receptors and subsequent phosphorylation and activation of Smad transcription factors driving gene transcription through binding to Smad-binding elements (SBE) on 
A

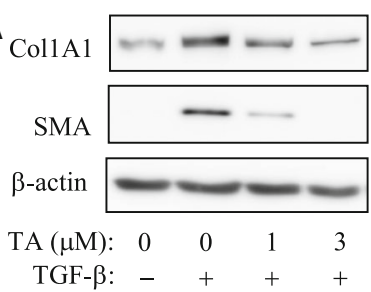

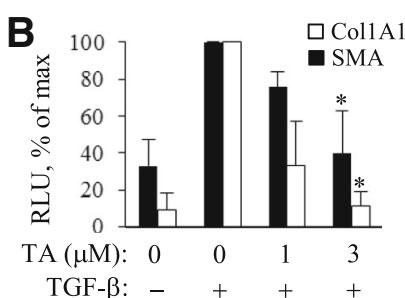

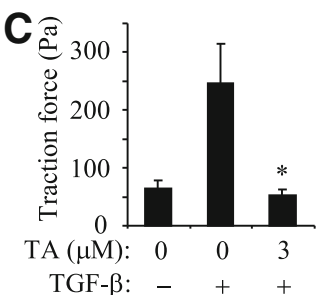

Fig. 1 Inhibition of myofibroblast differentiation by tannic acid. $\mathbf{a}$, b, Inhibition of Collagen-1 and SM-a-actin (SMA) expression by tannic acid (TA) in primary cultures of human lung fibroblasts in response to TGF- $\beta$ ( $1 \mathrm{ng} / \mathrm{ml}, 48 \mathrm{~h}$ ). Shown are the representative Western blots (a) and quantified densitometry (mean \pm SD) from at least 3 independent experiments. c, Inhibition of cell force generation by tannic acid in response to TGF- $\beta$ ( $1 \mathrm{ng} / \mathrm{ml}, 48 \mathrm{~h}$ ). Shown are the results of a representative experiment performed in triplicates. ${ }^{*}, p<0.05$ over TGF- $\beta$ without TA

the promoters of target genes. Pretreatment of cells with tannic acid did not affect acute Smad2 phosphorylation in response to TGF- $\beta$ (Fig. 2a). However, tannic acid significantly inhibited TGF- $\beta$-induced Smad-dependent gene transcription within $48 \mathrm{~h}$ of treatment, as determined using the SBE-luciferase reporter (Fig. 2b). These data suggest that the antifibrotic effect of tannic acid is independent of the initial TGF- $\beta$ signaling, but tannic acid still affects the overall Smad-dependent gene transcription in response to TGF- $\beta$. We have previously described a critical role of a sustained Smad2 phosphorylation for myofibroblast differentiation [36]. In the present study, we found that tannic acid significantly inhibited sustained Smad 2 phosphorylation induced by TGF- $\beta$ over 48 -h time period (Fig. 2c-f), which may explain the effect of tannic acid on myofibroblast differentiation.

To examine the effect of tannic acid on fibrogenesis in vivo, we used the bleomycin model of pulmonary fibrosis in mice. In this model, intratracheal administration of bleomycin results in an initial injury of alveolar epithelial cells followed by an inflammatory response during the first week, and development of pulmonary fibrosis at two to three weeks post bleomycin administration. To avoid a potential effect of tannic acid on the initial injury and inflammatory response, tannic acid was administered daily beginning on day-7 post bleomycin administration, and the lungs were analyzed on day 21. As shown in Fig. 3, bleomycin treatment resulted in a substantial lung fibrosis, which was significantly attenuated by tannic acid treatment (Fig. 3a). This was quantitatively determined by Ashcroft scoring (Fig. 3b), by measuring lung tissue surface area (Fig. 3c), and by calculating the histologic score (Fig. 3d). Treatment with tannic acid also resulted in a significantly reduced collagen deposition, as assessed biochemically by hydroxyproline assay (Fig. 3e); and in the amounts of Laemmli buffer-soluble Collagen-1, as assessed by
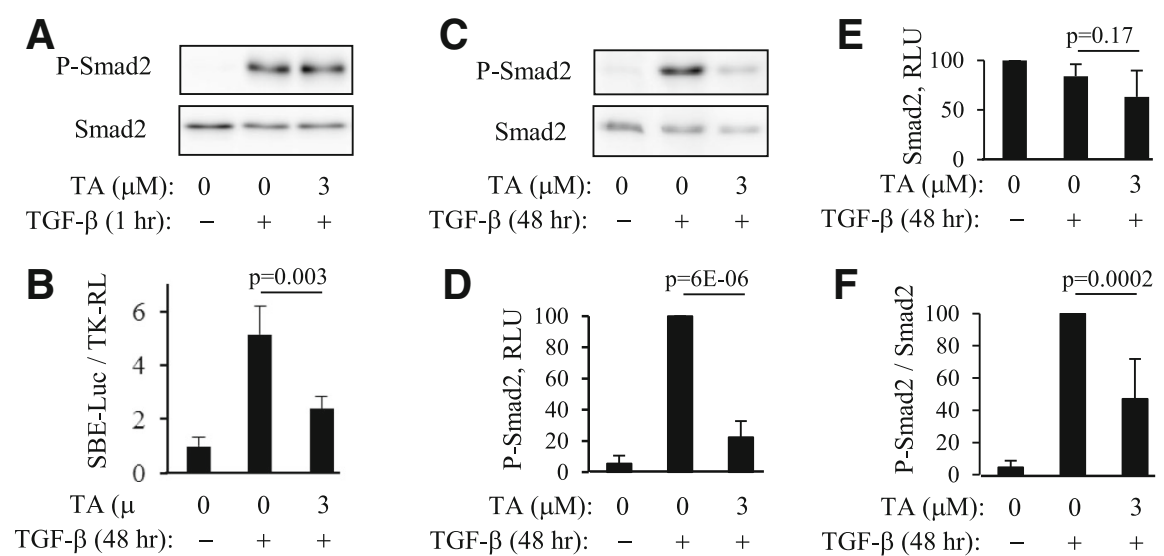

Fig. 2 Tannic acid inhibits sustained Smad2 phosphorylation and Smad-dependent gene transcription without affecting initial Smad2 phosphorylation in response to TGF- $\beta$. a, Pretreatment of HLF with tannic acid (TA) does not affect initial Smad2 phosphorylation in response to TGF- $\beta$ ( $1 \mathrm{ng} / \mathrm{ml})$. Shown are the representative results for P-Smad2 and Smad2 Western blotting from one of two independent experiments. b. Pretreatment with tannic acid inhibits TGF- $\beta$-induced Smad-dependent gene transcription, as assessed using SBE-luciferase reporter (shown are the representative results from one of two independent experiments performed in triplicates). $\mathbf{c}-\mathbf{f}$, Tannic acid inhibits the sustained phosphorylation of Smad2 in response to TGF- $\beta$. c, Representative P-Smad2 and Smad2 Western blot images; d-f, Densitometry of P-Smad2 (d), Smad2 (e), and normalized P-Smad2 / Smad2 (f) images. Shown are the means \pm SD from at least three independent experiments 


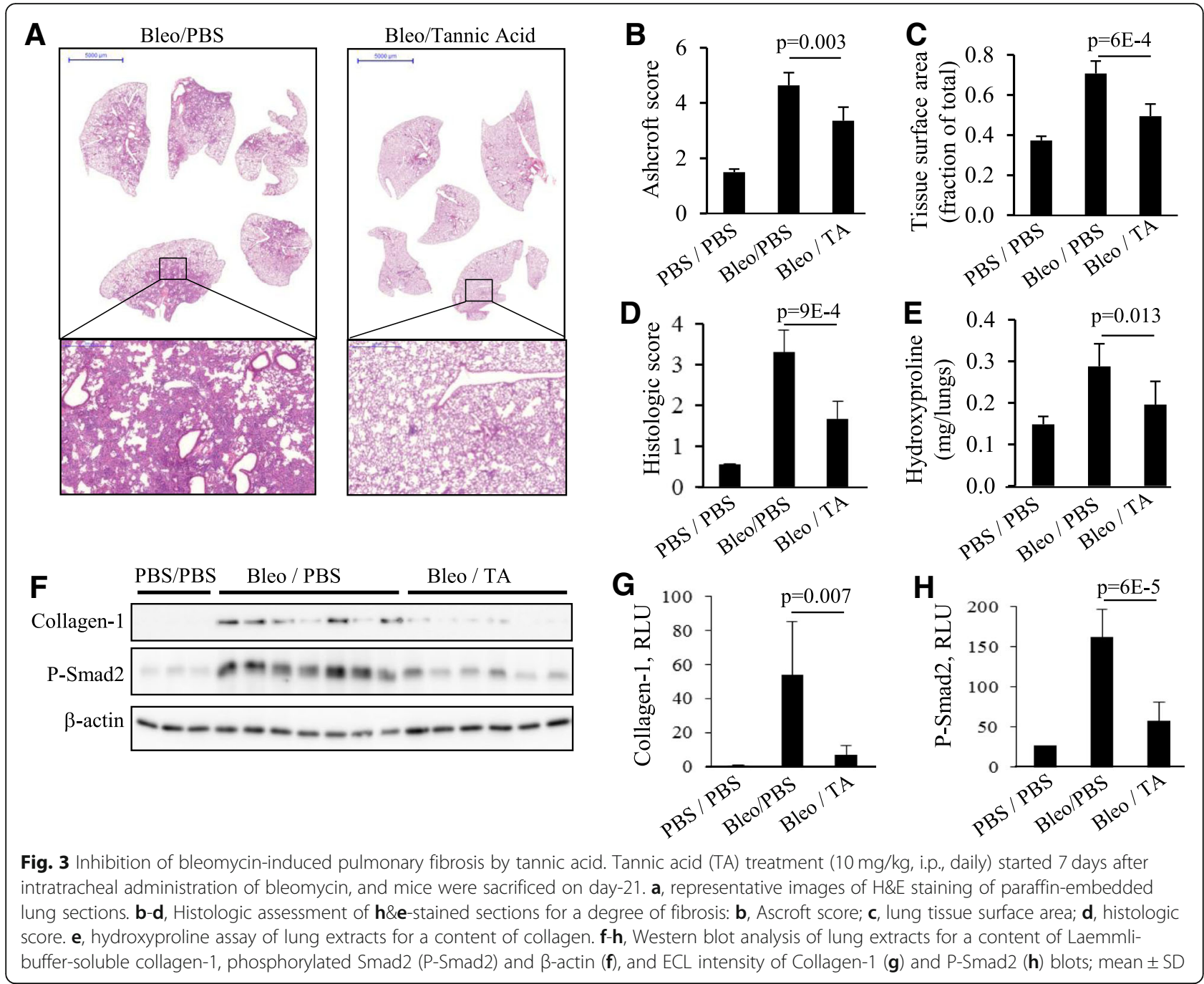

Western blotting of lung extracts with collagen-1 antibodies (Fig. 3f, g). Importantly, the bleomycintreated group showed highly elevated levels of phospho-Smad2, and this was significantly attenuated by tannic acid treatment (Fig. 3f, h). The images of entire Western blots for Collagen-1 and phospho-Smad2 are shown in Additional file 1: Figure S1. Together, these data demonstrate the antifibrotic effect of tannic acid in bleomycin model of pulmonary fibrosis, which is accompanied by inhibition of Smad2 phosphorylation by tannic acid treatment.

\section{Discussion}

In this report, we demonstrate for the first time the powerful anti-fibrotic effect of tannic acid in cultured human lung fibroblasts in vitro and in the bleomycin model of pulmonary fibrosis in vivo. Recent studies have demonstrated the protective effect of tannic acid in a rat model of pressure overload-induced cardiac hypertrophy induced by abdominal aortic banding through a reduction of oxidative stress, inflammation, and fibrosis [27]. It was also shown that tannic acid exerts significant liver-protective effects in mice with $\mathrm{CCl}_{4}$-induced liver fibrosis [28]. Our studies show the anti-fibrotic effect of tannic acid in bleomycin model of pulmonary fibrosis (Fig. 3). Importantly, the anti-fibrotic effect in vivo was evident when tannic acid treatment started 7 days post-bleomycin treatment the time when the initial injury is largely completed. Furthermore, under these treatment conditions, tannic acid significantly inhibited phosphorylation of Smad2 in bleomycin-treated lungs (Fig. 3f, h). It is well established that TGF- $\beta$ is released during fibrogenesis in bleomycin model of pulmonary fibrosis and contributes to this process [10,11, 13, 14]. Phosphorylation and nuclear localization of Smad2/3 during lung fibrogenesis in bleomycin model was also shown [33, 37]. Studies have also demonstrated the antifibrotic effect of therapeutic 
application of other drugs, accompanied by a reduced TGF- $\beta$ levels and Smad2/3 phosphorylation [33]. However, the mechanisms by which the antifibrotic drugs affect TGF- $\beta /$ Smad signaling in vivo remain poorly understood.

Our in vitro mechanistic studies suggest that inhibition TGF- $\beta$-induced myofibroblast differentiation by tannic acid may be mediated by its effect on a sustained (but not acute) Smad2 phosphorylation, whose critical role in the process of myofibroblast differentiation we recently demonstrated [36]. While our studies were in process, it has been reported that tannic acid inhibits TGF- $\beta$-induced epithelial-to-mesenchymal transition in epithelial cells [38]. However, the effective doses used in that study $(15-25 \mu \mathrm{M})$ were much higher than those in our study $(3 \mu \mathrm{M})$. In HLFs, tannic acid induced significant cell toxicity at concentrations higher than $10 \mu \mathrm{M}$, but not at $3 \mu \mathrm{M}$ (data not shown). The mentioned above study suggested two mechanisms for the action of tannic acid. First, the authors proposed that inhibition TGF- $\beta$ receptor-1 (TGFBR1) expression by tannic acid in epithelial cells could be one mechanism [38]. We observed a modest decrease in TGFBR1 expression after 24-h treatment of HLF with $3 \mu \mathrm{M}$ tannic acid; however, this did not affect the ability of TGF- $\beta$ to stimulate acute Smad2 phosphorylation (Additional file 2: Figure S2). Second, it was suggested that tannic acid may directly interact with TGF- $\beta$ and prevent its binding to TGF- $\beta$ receptors [38]. It was shown that tannic acid, at concentration of $15-25 \mu \mathrm{M}$ but not at $5 \mu \mathrm{M}$, inhibits TGF- $\beta$-induced acute Smad phosphorylation in epithelial cells [38]. Given that in our experiments, tannic acid, at concentration of $3 \mu \mathrm{M}$ that is effective in inhibition of myofibroblast differentiation, had no effect on TGF- $\beta$ induced acute Smad2 phosphorylation in HLFs (Fig. 2a), these proposed mechanisms do not explain the anti-fibrotic effect of tannic acid in our study and require further investigation. It would be also important to investigate if the similar effects and mechanisms of regulation of myfibroblast phenotype by tannic acid that we describe in this study would translate to human lung fibroblasts cultured from IPF patients. Finally, the effect of tannic acid on other cells (i.e. alveolar epithelial cells, macrophages and other immune cells) would be important to investigate in the context of pulmonary fibrosis.

\section{Conclusions}

This study demonstrates the anti-fibrotic effect of tannic acid in cultured human lung fibroblasts and in bleomycin model of pulmonary fibrosis. The anti-fibrotic mechanism of tannic acid involved at least in part the regulation of sustained Smad2 phosphorylation in response to TGF- $\beta$.

\section{Additional files}

Additional file 1: Figure S1. Images of the entire blots for Collagen-1 and P-Smad2 shown in Fig. 3d. (PDF $110 \mathrm{~kb}$ )

Additional file 2: Figure S2. Effect of tannic acid pretreatment on the acute $\mathrm{Smad} 2$ phosphorylation by TGF- $\beta$. HLF were pretreated with indicated concentrations of tannic acid (TA) for $1 \mathrm{~h}$ or $24 \mathrm{~h}$ followed by stimulation with TGF-b for $1 \mathrm{~h}$. Cell lysates were analyzed by Western blotting with antibodies as indicated. (PDF 31 kb)

\section{Abbreviations}

DMEM: Dulbecco's Modified Eagle's Medium; HLF: Human lung fibroblasts; HRP: Horseradish peroxidase; IPF: Idiopathic pulmonary fibrosis;

PA: Polyacrylamide; RI: Renilla; SDS: Sodium dodecyl sulphate; SMA: Smooth muscle a-actin; TA: Tannic acid; TGF: Transforming growth factor;

TGFBR: TGF- $\beta$ receptor; TK: Thymidine kinase

\section{Author contributions}

Conceptualization: JL, JJF, SNO, GMM, NOD. Methodology: JL, CYP, JJF, BC, RG, GM, NOD. Investigation: EBR, JL, SA, CYP, LC, LVS, RG, NOD. Formal Analysis: JL, SA, CYP, SNO, JJF, RG, NOD. Supervision: JJF, SNO, NOD. Writing - original draft: NOD. Writing - review \& editing: JL, CYP, SNO, RG, GMM, NOD. All authors read and approved the final manuscript.

\section{Funding}

Research reported in this publication was supported by the National Institutes of Health Award 1R56HL127395 (N.O.D.), National Center For Advancing Translational Sciences of the National Institutes of Health Award UL1TR000430 (N.O.D.); Falk Medical Research Catalyst Award (N.O.D.), and the Russian Scientific Foundation (L.V.S., S.N.O.).

\section{Availability of data and materials}

The data used and analyzed as well as human lung fibroblast cultures used during this study are available from the corresponding author upon reasonable request.

\section{Ethics approval and consent to participate}

Human lung fibroblasts (HLF) were isolated from human lungs rejected for transplantation through the Regional Organ Bank of Illinois (ROBI)/Gift of Hope. No IRB protocol is required for using lungs from deceased de-identified individuals.

\section{Consent for publication}

Not applicable.

\section{Competing interests}

The authors declare that they have no competing interests.

\section{Author details}

${ }^{1}$ Department of Medicine, Section of Pulmonary and Critical Care Medicine, the University of Chicago, 5841 S. Maryland Ave, MC6076, Chicago, IL 60637, USA. ${ }^{2}$ Molecular and Integrative Physiological Sciences, Harvard T.H. Chan School of Public Health, Boston, MA, USA. 'Laboratory of Biomembranes, Faculty of Biology, Lomonosov Moscow State University, Moscow, Russian Federation. ${ }^{4}$ Siberian Medical State University, Tomsk, Russian Federation.

Received: 26 March 2019 Accepted: 22 July 2019

Published online: 29 July 2019

\section{References}

1. Olson AL, Swigris JJ, Lezotte DC, Norris JM, Wilson CG, Brown KK. Mortality from pulmonary fibrosis increased in the United States from 1992 to 2003. Am J Respir Crit Care Med. 2007;176:277-84.

2. White ES, Lazar MH, Thannickal VJ. Pathogenetic mechanisms in usual interstitial pneumonia/idiopathic pulmonary fibrosis. J Pathol. 2003;201:343-54.

3. Hardie WD, Glasser SW, Hagood JS. Emerging concepts in the pathogenesis of lung fibrosis. Am J Pathol. 2009;175:3-16.

4. Noble PW, Homer RJ. Back to the future: historical perspective on the pathogenesis of idiopathic pulmonary fibrosis. Am J Respir Cell Mol Biol. 2005;33:113-20. 
5. Selman M, Pardo A. Idiopathic pulmonary fibrosis: an epithelial/fibroblastic cross-talk disorder. Respir Res. 2002;3:3.

6. Thannickal VJ, Toews GB, White ES, Lynch JP 3rd, Martinez FJ. Mechanisms of pulmonary fibrosis. Annu Rev Med. 2004:55:395-417.

7. Broekelmann TJ, Limper AH, Colby TV, McDonald JA. Transforming growth factor beta 1 is present at sites of extracellular matrix gene expression in human pulmonary fibrosis. Proc Natl Acad Sci U S A. 1991;88:6642-6.

8. Kaminski N, Allard JD, Pittet JF, Zuo F, Griffiths MJ, Morris D, Huang X, Sheppard D, Heller RA. Global analysis of gene expression in pulmonary fibrosis reveals distinct programs regulating lung inflammation and fibrosis. Proc Natl Acad Sci U S A. 2000;97:1778-83.

9. Sime PJ, Xing Z, Graham FL, Csaky KG, Gauldie J. Adenovector-mediated gene transfer of active transforming growth factor-beta1 induces prolonged severe fibrosis in rat lung. J Clin Invest. 1997;100:768-76.

10. Santana A, Saxena B, Noble NA, Gold LI, Marshall BC. Increased expression of transforming growth factor beta isoforms (beta 1, beta 2, beta 3 ) in bleomycin-induced pulmonary fibrosis. Am J Respir Cell Mol Biol. 1995:13:34-44

11. Phan SH, Kunkel SL. Lung cytokine production in bleomycin-induced pulmonary fibrosis. Exp Lung Res. 1992;18:29-43.

12. Kang HR, Cho SJ, Lee CG, Homer RJ, Elias JA. Transforming growth factor (TGF)-beta1 stimulates pulmonary fibrosis and inflammation via a Baxdependent, bid-activated pathway that involves matrix metalloproteinase12. J Biol Chem. 2007;282:7723-32.

13. Giri SN, Hyde DM, Hollinger MA. Effect of antibody to transforming growth factor beta on bleomycin induced accumulation of lung collagen in mice. Thorax. 1993:48:959-66.

14. Wang Q, Wang Y, Hyde DM, Gotwals PJ, Koteliansky VE, Ryan ST, Giri SN Reduction of bleomycin induced lung fibrosis by transforming growth factor beta soluble receptor in hamsters. Thorax. 1999;54:805-12.

15. Hinz B. Masters and servants of the force: the role of matrix adhesions in myofibroblast force perception and transmission. Eur J Cell Biol. 2006;85:175-81.

16. Leask A, Abraham DJ. TGF-beta signaling and the fibrotic response. FASEB J. 2004;18:816-27.

17. Phan SH. Fibroblast phenotypes in pulmonary fibrosis. Am J Respir Cell Mol Biol. 2003;29:587-92.

18. Tomasek JJ, Gabbiani G, Hinz B, Chaponnier C, Brown RA. Myofibroblasts and mechano-regulation of connective tissue remodelling. Nat Rev Mol Cell Biol. 2002;3:349-63.

19. Evans JN, Kelley J, Krill J, Low RB, Adler KB. The myofibroblast in pulmonary fibrosis. Chest. 1983:83:97S-8S.

20. Hinz B, Phan SH, Thannickal VJ, Galli A, Bochaton-Piallat ML, Gabbiani G. The Myofibroblast. One Function, Multiple Origins. Am J Pathol. 2007;170(6): 1807-16.

21. Phan SH. Role of the myofibroblast in pulmonary fibrosis. Kidney Int Suppl. 1996;54:546-8.

22. Thannickal VJ, Horowitz JC. Evolving concepts of apoptosis in idiopathic pulmonary fibrosis. Proc Am Thorac Soc. 2006;3:350-6.

23. Zhang HY, Phan $\mathrm{SH}$. Inhibition of myofibroblast apoptosis by transforming growth factor beta (1). Am J Respir Cell Mol Biol. 1999;21:658-65.

24. Leask A, Holmes A, Abraham DJ. Connective tissue growth factor: a new and important player in the pathogenesis of fibrosis. Curr Rheumatol Rep. 2002:4:136-42

25. Chung KT, Wong TY, Wei Cl, Huang YW, Lin Y. Tannins and human health: a review. Crit Rev Food Sci Nutr. 1998;38:421-64.

26. Hupkens P, Boxma H, Dokter J. Tannic acid as a topical agent in burns: historical considerations and implications for new developments. Burns. 1995;21:57-61.

27. Chu L, Li P, Song T, Han X, Zhang X, Song Q, Liu T, Zhang Y, Zhang J. Protective effects of tannic acid on pressure overload-induced cardiac hypertrophy and underlying mechanisms in rats. J Pharm Pharmacol. 2017:69:1191-207.

28. Chu X, Wang H, Jiang YM, Zhang YY, Bao YF, Zhang X, Zhang JP, Guo H, Yang F, Luan YC, Dong YS. Ameliorative effects of tannic acid on carbon tetrachloride-induced liver fibrosis in vivo and in vitro. J Pharmacol Sci. 2016;130:15-23.

29. Butler JP, Tolic-Norrelykke IM, Fabry B, Fredberg JJ. Traction fields, moments, and strain energy that cells exert on their surroundings. Am J Physiol Cell Physiol. 2002;282:C595-605.
30. Park CY, Zhou EH, Tambe D, Chen B, Lavoie T, Dowell M, Simeonov A, Maloney DJ, Marinkovic A, Tschumperlin DJ, et al. High-throughput screening for modulators of cellular contractile force. Integr Biol (Camb). 2015;7:1318-24.

31. Hubner RH, Gitter W, El Mokhtari NE, Mathiak M, Both M, Bolte H, FreitagWolf S, Bewig B. Standardized quantification of pulmonary fibrosis in histological samples. Biotechniques. 2008;44:507-11 514-507.

32. Borensztajn $K$, Bresser $P$, van der Loos C, Bot I, van den Blink B, den Bakker MA, Daalhuisen J, Groot AP, Peppelenbosch MP, von der Thusen JH, Spek CA. Protease-activated receptor-2 induces myofibroblast differentiation and tissue factor up-regulation during bleomycin-induced lung injury: potential role in pulmonary fibrosis. Am J Pathol. 2010;177:2753-64.

33. Lucattelli M, Fineschi S, Selvi E, Garcia Gonzalez E, Bartalesi B, De Cunto G, Lorenzini S, Galeazzi M, Lungarella G. Ajulemic acid exerts potent antifibrotic effect during the fibrogenic phase of bleomycin lung. Respir Res. 2016;17:49.

34. Kach J, Sandbo N, Sethakorn N, Williams J, Reed EB, La J, Tian X, Brain SD, Rajendran K, Krishnan R, et al. Regulation of myofibroblast differentiation and bleomycin-induced pulmonary fibrosis by adrenomedullin. Am J Physiol Lung Cell Mol Physiol. 2013;304:L757-64.

35. Zawel L, Dai JL, Buckhaults P, Zhou S, Kinzler KW, Vogelstein B, Kern SE. Human Smad3 and Smad4 are sequence-specific transcription activators. Mol Cell. 1998;1:611-7.

36. Ard S, Reed EB, Smolyaninova LV, Orlov SN, Mutlu GM, Guzy RD, Dulin NO. Sustained Smad2 phosphorylation is required for Myofibroblast transformation in response to TGF-beta. Am J Respir Cell Mol Biol. 2019:60:367-9

37. De Langhe E, Cailotto F, De Vooght V, Aznar-Lopez C, Vanoirbeek JA, Luyten $F P$, Lories RJ. Enhanced endogenous bone morphogenetic protein signaling protects against bleomycin induced pulmonary fibrosis. Respir Res. 2015;16:38.

38. Pattarayan D, Sivanantham A, Krishnaswami V, Loganathan L, Palanichamy R Natesan S, Muthusamy K, Rajasekaran S. Tannic acid attenuates TGF-beta1induced epithelial-to-mesenchymal transition by effectively intervening TGF-beta signaling in lung epithelial cells. J Cell Physiol. 2018;233:2513-25.

\section{Publisher's Note}

Springer Nature remains neutral with regard to jurisdictional claims in published maps and institutional affiliations.

\section{Ready to submit your research? Choose BMC and benefit from:}

- fast, convenient online submission

- thorough peer review by experienced researchers in your field

- rapid publication on acceptance

- support for research data, including large and complex data types

- gold Open Access which fosters wider collaboration and increased citations

- maximum visibility for your research: over $100 \mathrm{M}$ website views per year

At BMC, research is always in progress.

Learn more biomedcentral.com/submissions 